\title{
Relationship between Window and View Factors in the Workplace: A SEM Approach
}

\author{
Mercy Inikpi Achoba \\ Faculty of Built Environment and Surveying, Universiti Teknologi Malaysia 81310 UTM Johor Bahru, Johor \\ Roshida Abdul Majid \\ Faculty of Built Environment and Surveying, Universiti Teknologi Malaysia 81310 UTM Johor Bahru, Johor \\ Cyril Obinna Obiefuna \\ Department of Architectural Technology, Federal Polytechnic Idah, Kogi State, Nigeria
}

\begin{abstract}
Office occupants' have always preferred workplaces that have windows that connects them to the outside. Window access to the outside can influence occupants' satisfaction with the combination of other workplace features. This study aims to identify the window and view factors relationship in the workplace, to confirm the reliability and validity of the measurement and structural model. Adopting a cross-sectional survey design, primary data from five offices in the Kogi State of Nigeria with 267 respondents were collected by using the convenience sampling method and analysis was performed with the Statistical Package for Social Science version 23 and AMOS 22.0 version as the modelling tool. The study identified eleven vital factors that are interrelated in the relationship between windows and view in the workplace. They are referred to as latent construct namely; Window distance (WDB), Seating arrangement (SAB), Room height (FHB), Office size (OSB), Window position (WPB), Window Sill level (WLC), Window size (SWC), Window type (TWC), View content (CVC), View satisfaction (VSC), and Occupants' satisfaction (SAT). The result showed a valid model using the Structural Equation Model, and the effect of the current workplace negligence on occupants'. This study improves the existing knowledge on the window and view relationship in the workplace, and provide suggestions for Facility Managers, Architects, and Interior Designers on maintaining a healthy workplace environment.
\end{abstract}

\section{Article History}

Received : 16 July 2020

Received in revised form : 13 January 2021

Accepted : 04 February 2021

Published Online : 30 April 2021

\section{Keywords:}

Window, View, Workplace, Occupants, Structural Equation Model

\section{Corresponding Author Contact:}

mercy.inikpi.achoba@graduate.utm.my

DOI: 10.11113/ijbes.v8.n2.667

(C) 2021 Penerbit UTM Press. All rights reserved

\section{Introduction}

Office occupants' spend about one-third of their day in buildings. An office building mainly provides a workspace and an enabling environment for its occupants. The work environment is a combination of three environments which are technical, human, and organizational environments. The concern of the workplace environment is on the increase because about fifty per cent of occupants' lives are spent in an enclosed environment that significantly influences them. The workplace conditions greatly influence the degree to which environmental conditions influence occupants' satisfaction, well-being, and health (Aries, Veitch, \& Newsham, 2010; Jamrozik et al., 2019). Therefore, the workplace should be treated with due importance, for it is the immediate surroundings of man which he controls for his survival (Al horr et al., 2016; Frontczak \& Wargocki, 2011; Leder, Newsham, Veitch, Mancini, \& Charles, 2016; Madu, Asawo, \& Gabriel, 2017).

Studies indicate that the two most important factors to office occupants' are daylight and views provided by windows (Jamrozik et al., 2019). However, the most valued window benefit by building occupants' is the provision of view (Ozdemir, 2010). Windows are the transparent building elements that supply passive solar gain, ventilation, and view to the outside (Cuce, Young, \& Riffat, 2015). Maximizing the benefits of windows requires been knowledgeable of the complexity of the human- window 
interactions (Salonen et al., 2014). The features of window views and social density are part of the physical characteristics of office experience (Aries et al., 2010). Many types of research have been carried out on window relationships within the context of humanenvironment (Collins, 1976; Butler \& Biner, 1989); window size, shape, position preferences (D. l. Butler \& Biner, 1989; Heerwagen \& Orians, 1986); while some are centered on discovering the most significant contributions of windows (Dogrusoy \& Tureyen, 2007). Even though the study on occupants' satisfaction has been done from different angles across disciplines, the phrase "occupants' satisfaction" is yet to have a clear definition in the built environment (Kwon, Remøy, \& van den Bogaard, 2019). Window access to the outside can influence occupants' satisfaction with other features of the environment (Boubekri \& Haghighat, 1993; Konstantzos \& Tzempelikos, 2015).

Window views and its positive effect on occupants' well-being, health, and satisfaction have been continually recognized by researchers. The findings of such studies have created the need to understand the link between windows and people (Dogrusoy \& Tureyen, 2007). Research shows that office occupants' prefer spaces with windows (Verderber, Grice, \& Gutentag, 1987; Dogrusoy \& Tureyen, 2007). In a nutshell, office occupants' place more value on views from windows than its other benefits and psychological functions. Some researchers opine that a view to the outside vegetation through a window results to positive psychological effects and healing rate is increased due to the presence of windows (Herzog, Kaplan, \& Kaplan, 1976; Jiang, 2016; R. Kaplan, 1993; Ulrich et al., 1991). According to Kaplan (1993), occupants' having a window view of nature outside derive significant satisfaction, even without necessarily being in the natural setting. Window views can be aesthetically pleasing and provide a quick hiatus from office work (Leslie, 2003). The view from the window is connected to occupants' satisfaction within a room (Konstantzos et al., 2015)

\subsection{Theoretical Background}

A good understanding of theories related to windows and view is vital for the validation of the measurement model for this study. This study is based on two theories; Attention Restoration Theory (ART) and Stress Recovery Theory (SRT). The ART postulates that the concentration level of people gets better after spending time in nature or gazing at scenes of nature (Kaplan, 1987). An attentionrestoring experience can be an undemanding activity, like just having a stare at nature (Hellinga, 2013). The SRT posits that humans' exposed to green scenery enhances their capacity to recover from stressful events (Roger S Ulrich, 1993). The two theories are complementary in dealing with windows that offer positive benefits to the office occupants' (Hartig et al, 2003). Nevertheless, their point of departure is in what urges occupants' towards restorative scene; in the case of ART, it is the mental fatigue, while SRT it is physiological stress (Berto, 2014). Kaplan, R. (1993), refers to windows with views of nature as microrestorative settings that supply brief views with features of fascination, which are believed to lessen mental fatigue. Also, Hartig et al. (2003), opined that facilitating the recovery from stress requires windows to give occupants' a social and continuous visual connection to nature from indoors.
Having to connect occupants' with the view outside through windows has been related to occupant satisfaction (I Konstantzos \& Tzempelikos, 2015; Ozdemir, 2010). Kwon et al. (2019), posits that occupants' satisfaction in an office is based on the window proximity to the workspace and the type of task performed. Occupants' satisfaction with the quality of the environment influences their perception of comfort and health (Sant' Anna et al., 2018). However, occupants' dissatisfaction may arise from physical workplace conditions such as desk position, office type, building orientation amongst others (Samani, 2015). Research on offices and occupants' have focused more on thermal and visual comfort, while the view aspect and its influence on occupants' satisfaction are least investigated (Konstantzos et al., 2015).

\subsection{The Nigerian Situation}

The increasing rate at which Nigerian Government offices are on the path of becoming an unhealthy environment needs urgent attention. Workplace environment being a place where most the occupants' spent most of their time ought to be kept healthy. Regrettably, the office design has been significantly affected by the rise in staff strength that has led to more workspaces in the shared offices. There is an alteration on the required social density for workplaces. Measures to suppress reoccurrence in newer office designs have not been made despite such alterations in the office use and capabilities (Adedayo, Oyetola, Anunobi, \& Odine, 2015). Offices are becoming an unhealthy environment due to lack of space standards for office buildings in Nigeria (Zubairu \& Olagunju, 2003). The impact of physical work environment on occupants' is under-researched as stated by Morrison \& Macky, (2017), and modern offices rarely consider occupants comfort and satisfaction (Van Der Valk, Myers, Atkinson, \& Mohring, 2015). Therefore, there is need for the unhealthy trend created in Nigerian Government workplaces be stopped.

\subsection{Research Constructs and Hypothesis}

The development of these research constructs was drawn from the ART and SRT theories that emphasize that in an environment a window is required for a view and also stated by Hartig, Mang, \& Evans, (1991), that facilitating the recovery from stress requires windows to give occupants a visual connection to nature from indoors. The window, view, and workplace factors were considered as deduced from both theories. The workplace consists of the interrelationship existing between the occupants' and the work environment. Based on previous researches, window distance (Aries et al., 2010; Hellinga, 2013; Lindberg et al., 2018; Yildirim, Akalin-baskaya, \& Celebi, 2007); seating arrangement (Lindberg et al., 2018; Ne'eman, Sweitzer, \& Vine, 1984); room height (Ne'eman et al., 1984); office size (Butler \& Steuerwald, 1991), are the workplace constructs. The understanding of the entangled interactions between humans and window is paramount for effective window benefits utilization (Salonen et al., 2014). The window constructs are window position (Butler \& Steuerwald, 1991; Hellinga, 2013; Inan, 2013; Koohsari, Fayaz, \& Kari, 2015; C Koranteng, Essel, \& Nkrumah, 2015; Christian Koranteng, Nkrumah, \& Essel, 2016); window sill level ( Butler \& Steuerwald, 1991; Inan, 2013; Koohsari et al., 2015); window size (Boubekri, Hulliv, \& Boyer, 1991; D. L. Butler \& Steuerwald, 1991; C 
Koranteng et al., 2015); window type (Dogrusoy \& Tureyen, 2007), while view constructs are view content and view satisfaction (Aries et al., 2010; Leather et al., 1998; Lottrup et al., 2015; Matusiak \& Klöckner, 2016; Ozdemir, 2010). The view as stated by Lottrup et al., (2015), is a part of the portion of the workplace environment that continuously meets the occupant in the office.

This study aims to contribute to the understanding of the relationship between the workplace, windows and view factors with particular application to Nigeria, using Structural Equation Modelling. Based on the review of the literature, the following hypotheses are formulated;

H1-Window has a positive influence on the views received by the office occupants'.

H2-Window positively affects the workplace environment.

H3-Window positively influences the occupants'satisfaction

\subsection{Materials and Methods}

\subsection{Method for Data collection}

The survey method using questionnaire was used for the research. The questions were drawn from different researches (Aries et al., (2010), Dogrusoy \& Tureyen, (2007), Hellinga, (2013) and Woo, (2010)). The scale used is a 5 -point Likert scale. The content validity was achieved by engaging a team of specialized experts from the Built Environment. The team consisted of three Architects, two Landscape Architects, two Facility Managers, and one Building Technologist. The team were consulted based on the years of professional experience and availability to complete the task within the given time frame. Subsequently, their inputs were used to refine and finalize the questionnaire in terms of content and readability. The questionnaire is classified into four parts; Demographic data, workplace factors, windows and views factors, and occupants preferences. A pilot study was carried out before the field survey.

A Cross-sectional survey was carried out by distributing closedended questionnaires across five Government office buildings within Kogi State in Nigeria from July to September 2019. The data from the respondents was got by using a 5 -point Likert scale with the range starting from $1=$ strongly disagree to $5=$ strongly agree. The sampling technique used for this study is the convenience sampling method. The inclusion criteria of participants were that eligible participants are those that work in shared-room offices and open-plan offices. The office types were grouped based on predefined categorization from Danielsson \& Bodin, (2008). In total, 350 questionnaires were distributed but 331(94\%) questionnaires were retrieved. Questionnaires with an incomplete response and missing data of more than $10 \%$ were excluded resulting in a total of 267 questionnaires of valid samples with a $76 \%$ effective rate. All responses were anonymous to protect the privacy of participants. Awang, (2015) stated that Hair et al (2011) accepts that the minimum sample size is 200. The demography of the respondents is as shown in Table 1.

Table 1 Demographics of valid respondents

\begin{tabular}{|c|c|c|c|}
\hline Parameter & Value & Frequency & Percentage $\%$ \\
\hline \multirow[t]{2}{*}{ Gender } & Male & 166 & 62.2 \\
\hline & Female & 101 & 37.8 \\
\hline \multirow[t]{5}{*}{ Age } & Less than 30 & 117 & 43.8 \\
\hline & $31-40$ & 69 & 25.8 \\
\hline & $41-50$ & 56 & 21.0 \\
\hline & $51-60$ & 22 & 8.2 \\
\hline & Above 60 & 3 & 1.1 \\
\hline \multirow[t]{4}{*}{ Educational Qualification } & Secondary Education & 6 & 2.2 \\
\hline & Tertiary Education & 114 & 42.7 \\
\hline & Bachelors' Degree & 111 & 41.6 \\
\hline & Masters' Degree & 36 & 13.5 \\
\hline \multirow[t]{4}{*}{ Duration of Service } & Less than 5 & 99 & 37.1 \\
\hline & $5-10$ & 82 & 30.7 \\
\hline & $11-20$ & 68 & 25.5 \\
\hline & Above 20 & 18 & 6.7 \\
\hline \multirow[t]{4}{*}{ Current Work Specification } & Administrative Support & 87 & 32.6 \\
\hline & Managerial / Supervisory & 56 & 21.0 \\
\hline & Technical /Engineer/Professional & 109 & 40.8 \\
\hline & Sales / Marketing & 15 & 5.6 \\
\hline \multicolumn{2}{|l|}{ Total } & \multicolumn{2}{|l|}{267 Respondents } \\
\hline
\end{tabular}

\subsection{Data Analysis Of The Survey}

\subsection{Justification For SEM Selection}

Structural Equation Model (SEM) is a multivariate statistical method mostly used for studying relationships which exist and linking the latent constructs and the observed variables (indicators) in research (Qureshi \& Kang, 2015). SEM's footing rest in both factor analysis and multiple regression analysis. There is the possibility of estimating multiple and interrelated dependence relationships with SEM, also representing unobserved concepts in relationships and display the measurement error (Hair et al, 2017). A sample size of at least 200 normally distributed data is 
recommended when using SEM (Hox \& Bechger, 1999). This study got 267 responses, therefore SEM is applicable.

The two significant components of SEM are measurement model and structural model. The measurement model in SEM shows the estimated relationships between latent constructs and their observed indicators, while the structural model shows the estimation of the relationship between constructs. Confirmatory Factor Analysis (CFA) is a crucial part used to test the fitness of data for the hypothesized model (Chong, Nazim, \& Ahmad, 2014). In this study, a preliminary analysis was performed with the Statistical Package for Social Science (SPSS) version 23 and AMOS 22.0 version as the modelling tool.

\subsection{Kaiser-Meyer-Olkin (KMO)}

When applying Likert scales it is important to use Cronbach's alpha coefficient in determining the reliability and consistency of the constructs. Using SPSS version 23, Kaiser-Meyer-Olkin (KMO) and Bartlett's Test of Sphericity were conducted and the results as shown in Table 2 revealed that .000 is significant, indicating that the correlation matrix is not individualistic and the data set is suitable and acceptable with the value of .851. Therefore, having a value above .6 as suggested by Kaiser, 1970 as cited by Pallant, J. (2016) indicates that factor analysis is appropriate.

Table 2 Results of KMO and Bartlett's Test

\begin{tabular}{|l|l|l|}
\hline \multicolumn{2}{|c|}{ KMO and Bartlett's Test } \\
\hline Kaiser-Meyer-Olkin Measure of Sampling Adequacy & .851 \\
\hline Bartlett's Test of Sphericity & Approx. Chi-Square & 20850.995 \\
\hline & df & 1953 \\
\hline & Sig. & .000 \\
\hline
\end{tabular}

\subsection{Confirmatory Factor Analysis}

\subsubsection{Construct Reliability}

The Analysis of Moment Structures (AMOS) software version 22 was used for the Confirmatory Factor Analysis (CFA). The screening of the data was done to ensure univariate and multivariate normality and removal of outliers. The factors used for this research have Cronbach alpha all above 0.7 , thus indicating a great level of internal consistency. The use of AMOS software also requires that reliability and validity test is first carried out before using the Structural Equation Model (SEM). Table 4 shows the results of reliability and validity analysis for the present study. Composite Reliability (CR) and Average Variance Extracted (AVE) of the latent constructs are all above the required 0.6 and 0.5 respectively (Z. Awang, 2015). The model fitness of the data used is determined by using at least one Fitness Index from each category of model fit (Holmes-Smith, 2006; Hooper, Coughlan, \& Mullen, 2008; Parry, n.d.). The latent constructs are eleven as listed in Table 4.

\subsubsection{Construct Validity}

The CFA is a validating procedure in the Structural Equation Model (Awang, 2015). Items having low factor loadings in the model are removed to achieve Fitness Indexes. For this study, the CFA was run individually for each latent construct and variables showing low factor loadings were deleted, while identified pairs of redundant items through Modification Indices (MI) resulted in covariation between the errors of redundant items. Covariation constrains the redundancy effects thereby increasing the model fitness. The following are the variables with covariance; WDB3-WDB4, SAB2SAB4, FHB1-FHB5, WPB3-WPB6, WLC3-WLC4, VSC3-VSC6. The deleted variables through individual CFA are; WDB6, SAB6, WPB4, WLC6, VSC4, SWC5, TWC2, TWC6.

The individual CFA was then pooled together to assess the measurement model of latent constructs. The initial measurement model contained eleven latent constructs that are inter-correlated, 56 observed variables, and with the measurement error shown on each indicator. The initial CFA iteration of the measurement model showed good factor loadings above 0.6 except for CVC2 and CVC4 which had low factors of $<0.6$. The absolute fitness indices indicated a good fit; CFI is 0.945 , IFI is 0.945 , TLI is $0.941, \mathrm{P}$ is 0.000 , RMSEA is 0.052 , and with a ChiSq/df $=1.731$. The second iteration after deleting the two low factor observed variables, the fitness indices showed RMSEA $=0.053, \mathrm{IFI}=0.947, \mathrm{TLI}=0.942$, $\mathrm{P}=0.000$, ChiSq $/ \mathrm{df}=1.760$. The following output was generated based on the response of the respondents. According to the literature, if the values of TLI, CFI, IFI, approach 0.95, then the models are a good fit (Bentler \& Bonett, 1980). The composite reliability (CR) score, constructs Cronbach's alpha, and the average variance (AVE) indices were used to determine convergent validity. Preferably, CR should be higher than AVE (Awang, 2015).

Table 3 Summary of the fitness indices results for the measurement model

\begin{tabular}{|l|l|l|l|l|l|l|l|}
\hline Category's Name & \multicolumn{2}{|l|}{ Parsimonious Fit } & Absolute fit & Incremental fit & Incremental fit & Absolute fit \\
\hline Fitness Indexes & Chi-square & $\mathrm{df}$ & $\begin{array}{l}\text { Chisq/ } \\
\mathrm{df}\end{array}$ & CFI & IFI & TLI & RMSEA \\
\hline Acceptance level & $\begin{array}{l}\text { Chisq/ } \\
<3.0\end{array}$ & & & CFI $>0.90$ & IFI $>0.90$ & TLI $>0.90$ & RMSEA <0.08 \\
\hline Initial value & 2464.521 & 1424 & 1.731 & .945 & .945 & .941 & .052 \\
\hline Revised value & 2318.461 & 1317 & 1.760 & .947 & .947 & .942 & .053 \\
\hline MODEL IS ACCEPTED
\end{tabular}


Table 4 Results of Reliability and Validity Analysis

\begin{tabular}{|c|c|c|c|c|c|c|c|}
\hline \multirow{2}{*}{$\begin{array}{l}\text { Item description } \\
\text { (Construct) }\end{array}$} & \multirow{2}{*}{$\begin{array}{ll}\text { No of } \\
\text { Items }\end{array}$} & \multirow[t]{2}{*}{ Variables } & \multicolumn{2}{|c|}{ Factor Loading } & \multirow{2}{*}{$\begin{array}{l}\text { Cronbach's } \\
\text { Alpha Value } \\
\text { Above } 0.7\end{array}$} & \multirow{2}{*}{$\begin{array}{l}\text { Composite } \\
\text { Reliability } \\
(\mathrm{CR}) \\
\text { Above } 0.6 \\
\end{array}$} & \multirow{2}{*}{$\begin{array}{l}\text { Average } \\
\text { Variance } \\
\text { (AVE) } \\
\text { Above } 0.5 \\
\end{array}$} \\
\hline & & & Initial & Revised & & & \\
\hline \multirow{5}{*}{$\begin{array}{l}\text { WDB- } \\
\text { Window } \\
\text { distance }\end{array}$} & WDB1 & The window is too close to workspace & .98 & \multirow{5}{*}{$\begin{array}{l}\text { NO } \\
\text { MODIFICATION }\end{array}$} & \multirow[t]{5}{*}{0.931} & \multirow[t]{5}{*}{0.943} & \multirow[t]{5}{*}{0.772} \\
\hline & WDB2 & Window distance is less than 2 meters & .95 & & & & \\
\hline & WDB3 & Window distance is between $2-4$ meters & .76 & & & & \\
\hline & WDB4 & Window distance is above 4 meters & .69 & & & & \\
\hline & WDB5 & You are satisfied with window distance & .97 & & & & \\
\hline \multirow{5}{*}{$\begin{array}{l}\text { SAB- } \\
\text { Seating } \\
\text { arrangement }\end{array}$} & SAB1 & Workspace is arrangement is a distraction & 1.00 & \multirow{5}{*}{ MODIFICATION } & \multirow[t]{5}{*}{0.932} & \multirow[t]{5}{*}{0.969} & 0.862 \\
\hline & SAB2 & Having a clear view from workspace & .81 & & & & \\
\hline & SAB3 & Near an exterior wall & .97 & & & & \\
\hline & SAB4 & Near a window & .87 & & & & \\
\hline & SAB5 & Near the core & .97 & & & & \\
\hline FHB- & FHB1 & Floor to ceiling is too high & .88 & & 0.973 & 0.972 & 0.854 \\
\hline Room height & FHB2 & Space above when seated negatively affects & .93 & NO & & & \\
\hline & FHB3 & Height affects the concentration level & .96 & & & & \\
\hline & FHB4 & Height negatively affects the window size & .97 & MODIFICATION & & & \\
\hline & FHB5 & Indifferent about the room height & .80 & & & & \\
\hline & FHB6 & Height negatively affects the office shape & .99 & & & & \\
\hline OSB- & OSB1 & Office size is adequate & .85 & & 0.935 & 0.935 & 0.707 \\
\hline Office size & OSB2 & Office size is attractive & .78 & $\mathrm{NO}$ & & & \\
\hline & OSB3 & Size is suitable for workspace arrangement & .89 & & & & \\
\hline & OSB4 & Size appears to be narrow & .84 & MODIFICATION & & & \\
\hline & OSB5 & Shape is rectangular & .81 & & & & \\
\hline & OSB6 & Satisfied with the office size & .87 & & & & \\
\hline WPB- & WPB1 & Window position is centralized in the wall & .80 & & 0.968 & 0.962 & 0.837 \\
\hline Window & WPB2 & The window is on the external wall & 1.00 & $\mathrm{NO}$ & & & \\
\hline position & WPB3 & Window position is adjacent my workspace & .86 & MODIFICATION & & & \\
\hline & WPB5 & Window position is behind my workspace & .98 & & & & \\
\hline & WPB6 & Window position positively affects occupants & .92 & & & & \\
\hline SWC- & WLC1 & Sill level negatively affect window view & .73 & & 0.929 & 0.925 & 0.715 \\
\hline Window & WLC2 & Sill level serves as protection when seated & .96 & $\mathrm{NO}$ & & & \\
\hline level & WLC3 & Sill level is above 900 meters & .77 & MODIFICATION & & & \\
\hline & WLC4 & Sill level allows for a clearer view & .79 & & & & \\
\hline & WLC5 & Satisfied with the height of the window sill level & .95 & & & & \\
\hline SWC- & SWC1 & Window size is sufficient for the office & .85 & & 0.917 & 0.913 & 0.677 \\
\hline Window size & SWC2 & Window size provides adequate view & .80 & $\mathrm{NO}$ & & & \\
\hline & SWC3 & Window size causes distractions & .78 & MODIFICATION & & & \\
\hline & SWC4 & Window size is too large & .79 & & & & \\
\hline & SWC6 & Window size positively affects occupants & .89 & & & & \\
\hline TWC- & TWC1 & Window type has clear glass for viewing & .91 & & 0.919 & 0.904 & 0.707 \\
\hline Window type & TWC3 & Window type is operable & .95 & $\mathrm{NO}$ & & & \\
\hline & TWC4 & Window type is attractive & .65 & MODIFICATION & & & \\
\hline & TWC5 & Window type has positive effects on occupants & .83 & & & & \\
\hline $\mathrm{CVC}-$ & CVC1 & View contains sky, showing clouds from my seat & .98 & .97 & 0.860 & 0.977 & 0.934 \\
\hline View content & CVC2 & It is a contains sky, landscape, and neighbourhood & .51 & DELETED & & & \\
\hline & CVC3 & View contains the landscape (grasses, shrubs, trees) & .97 & .97 & & & \\
\hline & CVC4 & The view contains forest and bushes & .38 & DELETED & & & \\
\hline & CVC5 & View contains buildings, car parks, roads & .96 & .96 & & & \\
\hline VSC- & VSC1 & Viewing scenes from the window is refreshing & .94 & & 0.916 & 0.924 & 0.710 \\
\hline View & VSC2 & You are satisfied with the view from your seat & .68 & NO & & & \\
\hline satisfaction & VSC3 & Viewing the scenery outside makes you relaxed & .84 & MODIFICATION & & & \\
\hline & VSC5 & View is affected by workplace position & .87 & & & & \\
\hline & VSC6 & You often look out through the window & .86 & & & & \\
\hline SAT- & SAT1 & My work is simple and demands little concentration. & .78 & & 0.926 & 0.926 & 0.717 \\
\hline Occupants' & SAT2 & My work requires deep thought and concentration. & .79 & $\mathrm{NO}$ & & & \\
\hline satisfaction & SAT3 & I can accomplish a great deal each day. & .82 & MODIFICATION & & & \\
\hline & SAT4 & I feel stressed concerning my work. & .97 & & & & \\
\hline & SAT5 & I regard my work as interesting and stimulating. & .86 & & & & \\
\hline
\end{tabular}

\subsection{Structural Model}

The structural model represents the relationships existing between the latent constructs. Based on the theory, the latent constructs from the measurement model were classified into three secondorder latent constructs namely; WINF (Window factors), WFAC (Workplace factors), VIEF (View factors), and eleven sub-latent constructs. Using AMOS, the process of validation of the model is 
required for the transformation of the measurement model into a structural model for analysis. Table 5 shows the results for both the initial and modified structural equation model for the windows and views relationships in the workplace. The initial output had the following: Chi-square $=3611.382, \mathrm{df}=1370$, Ratio $=2.636$, CFI $=.881, \mathrm{IFI}=.881, \mathrm{TLI}=.875, \mathrm{RMSEA}=.078$. Further adjustment was carried out to ensure the fitness of the model. Thus, three items with their error variances were deleted based on the output of the Modification Indices viz: VSC5, VSC1, and TWC3. Consequently, the values of the modified model are: Chisquare $=2734.607, \mathrm{df}=1217$, Ratio $=2.247, \mathrm{CFI}=.910, \mathrm{IFI}=.910$, TLI $=.906, \quad$ RMSEA $=.068$. The summary of factor loadings and the validity of the constructs of windows and view relationship in the workplace is shown in Table 6.

Table 5 Summary of Fitness indices results for the structural model

\begin{tabular}{|l|l|l|l|l|l|l|l|}
\hline Category's Name & \multicolumn{3}{|l|}{ Parsimonious Fit } & Absolute fit & Incremental fit & Incremental fit & Absolute fit \\
\hline Fitness Indexes & $\begin{array}{l}\text { Chi- } \\
\text { square }\end{array}$ & df & $\begin{array}{l}\text { Chisq/ } \\
\text { df }\end{array}$ & CFI & IFI & TLI & RMSEA \\
\hline Acceptance level & & & $\begin{array}{l}\text { Chisq }< \\
3.0\end{array}$ & CFI $>0.90$ & IFI $>0.90$ & TLI $>0.90$ & RMSEA <0.08 \\
\hline Initial value & 3611.382 & 1370 & 2.636 & .881 & .881 & .875 & .078 \\
\hline Revised value & 2734.607 & 1217 & 2.247 & .910 & .910 & .906 & .068 \\
\hline \multicolumn{7}{|l|}{ MODEL IS ACCEPTED } \\
\hline
\end{tabular}

Table 6 Summary of factor loadings and validity

\begin{tabular}{|c|c|c|c|c|c|c|}
\hline \multirow[t]{2}{*}{ Code } & \multirow{2}{*}{$\begin{array}{l}\text { Item description } \\
\text { (Construct) }\end{array}$} & \multirow{2}{*}{$\begin{array}{l}\text { No of } \\
\text { Items }\end{array}$} & \multicolumn{2}{|c|}{ Factor loading } & \multirow{2}{*}{$\begin{array}{l}\text { Composite } \\
\text { Reliability } \\
(\mathrm{CR}) \\
\text { Above } 0.6\end{array}$} & \multirow{2}{*}{$\begin{array}{l}\text { Average Variance } \\
\text { (AVE) } \\
\text { Above } 0.5\end{array}$} \\
\hline & & & Initial & Revised & & \\
\hline \multirow[t]{22}{*}{ Workplace factors } & \multirow{5}{*}{$\begin{array}{l}\text { WDB } \\
\text { (Window distance) }\end{array}$} & WDB1 & .98 & .98 & \multirow[t]{5}{*}{0.935} & \multirow[t]{5}{*}{0.748} \\
\hline & & WDB2 & .94 & .94 & & \\
\hline & & WDB3 & .73 & .73 & & \\
\hline & & WDB4 & .66 & .65 & & \\
\hline & & WDB5 & .97 & .97 & & \\
\hline & \multirow{5}{*}{$\begin{array}{l}\text { SAB } \\
\text { (Seating } \\
\text { arrangement) }\end{array}$} & SAB1 & 1.00 & 1.00 & \multirow[t]{5}{*}{0.963} & \multirow[t]{5}{*}{0.841} \\
\hline & & SAB2 & .75 & .75 & & \\
\hline & & SAB3 & .98 & .98 & & \\
\hline & & SAB4 & .84 & .85 & & \\
\hline & & SAB5 & .98 & .98 & & \\
\hline & \multirow{6}{*}{$\begin{array}{l}\text { FHB } \\
\text { (Room height) }\end{array}$} & FHB1 & .92 & .92 & \multirow[t]{6}{*}{0.981} & \multirow[t]{6}{*}{0.895} \\
\hline & & FHB2 & .95 & .94 & & \\
\hline & & FHB3 & .97 & .97 & & \\
\hline & & FHB4 & .98 & .98 & & \\
\hline & & FHB5 & .87 & .87 & & \\
\hline & & FHB6 & 1.00 & .99 & & \\
\hline & \multirow{6}{*}{$\begin{array}{l}\text { OSB } \\
\text { (Office size) }\end{array}$} & OSB1 & .90 & .90 & \multirow[t]{6}{*}{0.958} & \multirow[t]{6}{*}{0.793} \\
\hline & & OSB2 & .84 & .84 & & \\
\hline & & OSB3 & .92 & .92 & & \\
\hline & & OSB4 & .89 & .89 & & \\
\hline & & OSB5 & .87 & .87 & & \\
\hline & & OSB6 & .92 & .92 & & \\
\hline \multirow[t]{14}{*}{ Window factors } & \multirow{5}{*}{$\begin{array}{l}\text { WPB } \\
\text { (Window position) }\end{array}$} & WPB1 & .91 & .91 & \multirow[t]{5}{*}{0.982} & \multirow[t]{5}{*}{0.915} \\
\hline & & WPB2 & 1.00 & 1.00 & & \\
\hline & & WPB3 & .92 & .92 & & \\
\hline & & WPB5 & .99 & .99 & & \\
\hline & & WPB6 & .96 & .96 & & \\
\hline & \multirow{5}{*}{$\begin{array}{l}\text { WLC } \\
\text { (Window sill level) }\end{array}$} & WLC1 & .91 & .91 & \multirow[t]{5}{*}{0.972} & \multirow[t]{5}{*}{0.874} \\
\hline & & WLC2 & .99 & .99 & & \\
\hline & & WLC3 & .89 & .89 & & \\
\hline & & WLC4 & .90 & .90 & & \\
\hline & & WLC5 & .98 & .98 & & \\
\hline & \multirow{4}{*}{$\begin{array}{l}\text { SWC } \\
\text { (Window size) }\end{array}$} & SWC1 & .91 & .91 & 0.946 & 0.779 \\
\hline & & SWC2 & .86 & .86 & & \\
\hline & & SWC3 & .85 & .85 & & \\
\hline & & SWC4 & .86 & .86 & & \\
\hline
\end{tabular}




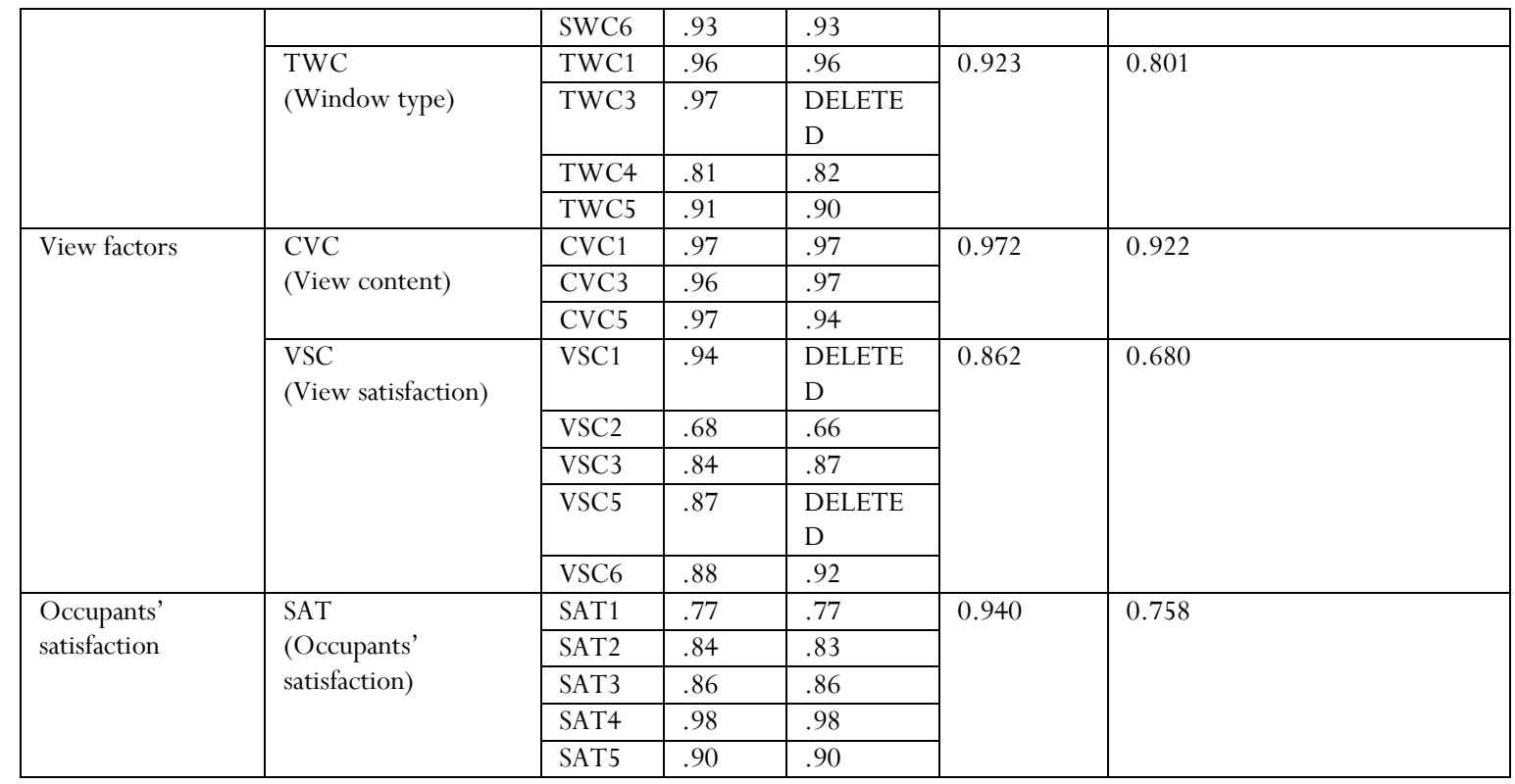

\subsection{Discussion of Findings}

The final output in Figure 2 shows the interaction outcome of all the constructs in the path diagram. This research adopted standardized regression weight alongside squared multiple correlations with the value of R2, due to its benefit of having a better interpretation of the entire interactions of the constructs in the model. As stated in Kwon \& Remøy, (2019), R2 shows the percentage of variation in the independent variables. Hence, the explanation of the model gets better as the R2 value gets higher. Generally, R2 values are described as follows; 0.75 as strong, 0.5 as moderate, and 0.25 as weak (Henseler, Ringle, \& Sinkovics, 2009; Wong, 2013).

In Table 3, all Fitness Indexes achieved the required level thereby indicating the validity of the constructs for the model. The model in Table 7 shows that the p-values are all highly significant having $\mathrm{p}<0.005$. Figure 2 output reveals that the correlation between the constructs are below the threshold of 0.85 indicating that redundancy does not exist among the components. All factor loadings are positive and with high values indicating that all items are important in measuring the constructs respectively. The R2 for WFAC sub-constructs shows OSB (.35) and FHB (.34) as moderate, while SAB (.18), and $\operatorname{WDB}(.16)$ were lower.

The low output for SAB and WDB is an indication that the data set used is reflecting the degrading current situation in shared-room and open-plan offices in Nigeria as regards to the workplace seating arrangement and their proximity to the windows. According to Oseland (2009), the current trends in building reveals that psychological factors are generally not fully considered. VIEF subconstructs showed R2 for CVC (.93) to be strong, and VSC (0.05) as quite weak. This weak $\mathrm{R} 2$ value could be attributed to the office occupants' not being satisfied with the content of the present view available from the windows since the majority of the offices are surrounded by a built view. Research has shown that people prefer natural view overbuilt view (Hellinga, 2013). Also, some studies have opined that the information content of a window view is a determinant for views being preferred over others (R. Kaplan \& Kaplan, 1989). In the office setting, having access to natural environments has a restorative effect on attention.

The WINF sub-constructs also revealed R2 as follows; WPB (.39), WLC (.51), SWC (.34), and TWC (.94). The TWC shows an R2 strong value indicating that the office occupants are satisfied with Window type. WPB and SWC reveal values that are within the moderate range, notwithstanding these values indicate that the window position and window size do not contribute strongly enough to the psychological satisfaction of the office occupants. Windows should be positioned to promote physical and psychological health (Moore, 1981; R. S. Ulrich, 1984). Providing a comfortable working environment is salient to allow the office occupants' focus on their task, thereby ensuring the quality of life at workplace and better performance of occupants' (Kamarulzaman et al,2011).

The overall R2 for the model is .53 meaning that the model has a moderate value as it captures $53 \%$ of the estimate on WINF by including VIEF, WFAC and SAT. It proves that the existing relationship between windows and view in this model is not strong. As stated in Thompson \& Bruk-Lee (2019), Organizations should proffer design solutions whereby the physical work environment will allow occupants' have maximum access and exposure to nature in the office. Several studies have shown that windows and views through the window promote physical and psychological health, 
with these natures' healing abilities it is expedient to ensure occupants are exposed to nature for improved wellbeing and strain reduction (Thompson \& Bruk-Lee, 2019).

The model is to reveal the relationship that exists between windows and views in the workplace to discourage the abuse of social density and lack of space standards policy that is gradually causing havoc in the Nigerian Government offices whereby the importance of occupants having access to an outside view is undermined. It is usually presumed that better work outcomes are produced by office occupants' who are more satisfied with the physical environment (Kamarulzaman et al., 2011).

Table 7 shows that the three research hypothesis $\mathrm{H} 1, \mathrm{H} 2$, and $\mathrm{H} 3$ are significant and have positive effects on window factors. Therefore, the hypotheses are all supported.

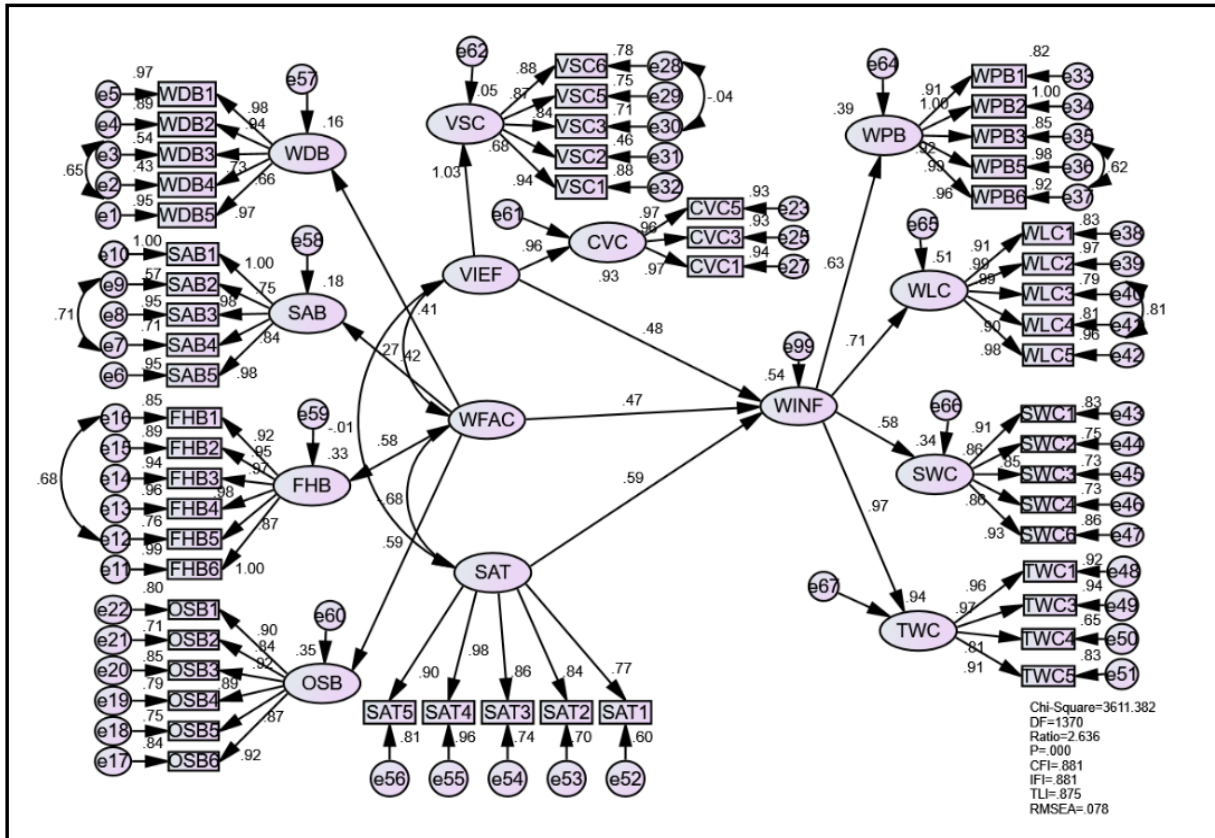

Figure 1 Initial Structural Equation Model of Windows and view relationship

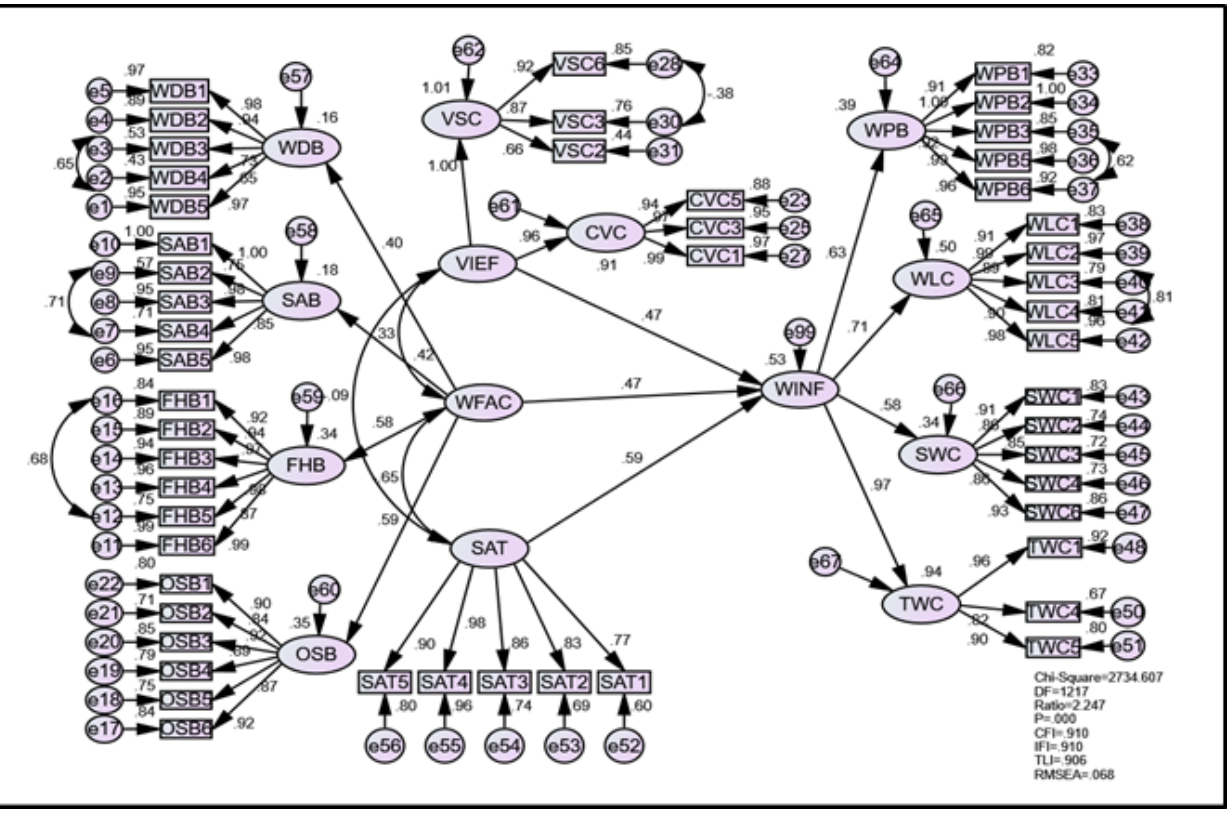

Figure 2 Modified Structural Equation Model of Window and View Relationship 
Table 7 Significant Effect of Window and View Relationship in the Workplace

\begin{tabular}{|l|l|l|l|l|l|l|}
\hline Construct & Path & Construct & Estimates & S.E. & C.R. & P \\
\hline WINF & $<---$ & VIEF & .605 & .039 & 15.496 & $* * *$ \\
\hline WINF & $<---$ & WFAC & .689 & .038 & 17.967 & $* * *$ \\
\hline WINF & $<---$ & SAT & .862 & .024 & 35.206 & $* * *$ \\
\hline WDB & $<---$ & WFAC & .605 & .039 & 15.496 & $* * *$ \\
\hline SAB & $<---$ & WFAC & .689 & .038 & 17.967 & $* * *$ \\
\hline FHB & $<---$ & WFAC & .862 & .024 & 35.206 & $* * *$ \\
\hline OSB & $<---$ & WFAC & .983 & .020 & 50.048 & $* * *$ \\
\hline WPB & $<---$ & WINF & .685 & .033 & 20.615 & $* * *$ \\
\hline WLC & $<---$ & WINF & .916 & .020 & 45.123 & $* * *$ \\
\hline SWC & $<---$ & WINF & .594 & .038 & 15.600 & $* * *$ \\
\hline TWC & $<---$ & WINF & .968 & .014 & 68.458 & $* * *$ \\
\hline VSC & $<---$ & VIEF & .992 & .017 & 58.626 & $* * *$ \\
\hline CVC & $<---$ & VIEF & .911 & .037 & 24.316 & $* * *$ \\
\hline
\end{tabular}

\subsection{Conclusion}

Windows in the workplace environment are important to the occupants' for satisfying both physical and psychological human needs. The visual connection with nature through the window positively influences the occupants' satisfaction in the workplace. This study identified the influential components of windows and view in the workplace model. The analysis provides the relationship that is focused on Government office occupants' in Nigeria particularly in Kogi State. The outcome of their relationships shows that SAB (seating arrangement) and WDB (window distance) having lower R2 is an indication that the current trend of neglecting workspace arrangement and proximity to windows is breading an unhealthy environment for its occupants'. The overall R2 for the model is a bit above $50 \%$, this is an indication than urgent measures for sustaining a healthy workplace environment should be instituted. The R2 value 53\% may have been better if the necessary conditions for the workplace were met.

The findings of this study hypothetically improve the existing literature on the workplace environment and the importance of window view out, while it also provides practical suggestions that will assist in the policy making on improvement on workplace design and also, for effective monitoring and enforcement of office space allocation standards.

The findings in this study will provide suggestions for Facility managers, Interior designers, Architects, and other Building stakeholders for the effective implementation and adherence of space standards in Government office buildings.

The study focused on data from Government offices in Nigeria particularly offices that have more than one workspace, therefore the conclusions may differ for other Countries.

\section{Conflict of interest}

The authors declare that there is no conflict of interest.

\section{References}

Adedayo, F. O., Oyetola, S. A., Anunobi, A. I., \& Odine, L. C. (2015). User Satisfaction with Space Flexibility in Selected Tertiary Institutions in Niger State, Nigeria. In 6th West Africa Built Environment Research (WABER) Conference . 1185-1200.

Al horr, Y., Arif, M., A.K, K., A, M., M, K., \& E, E. (2016). Occupant productivity and office indoor environment quality: a review of the literature. Building and Environment, 105: 45 https://doi.org/http://dx.doi.org/10.1016/j.buildenv.2016.06.001

Aries, M. B. C. C., Veitch, J. A., \& Newsham, G. R. (2010). Windows, view, and office characteristics predict physical and psychological discomfort. Journal of Environmental Psychology, 30(4): 533-541. https://doi.org/10.1016/j.jenvp.2009.12.004

Awang, Z. (2015). Chapter 6 : Data Analysis: Model Fit Analysis and Hypotheses Testing, 0(Byrne), 125-143.

Berto, R. (2014). The role of nature in coping with psycho-physiological stress: A literature review on restorativeness. Behavioral Sciences, 4(4): 394 409. https://doi.org/10.3390/bs4040394

Boubekri, M., \& Haghighat, F. (1993). Windows and Environmental Satisfaction: A Survey Study of an Office Building. Indoor and Built Environment, 2(3): 164-172. https://doi.org/10.1177/1420326X9300200305

Boubekri, M., Hulliv, R. B., \& Boyer, L. L. (1991). Impact of window size and sunlight penetration on office workers' mood and satisfaction. Environment and Behavior, 23(4): 474-493.

Butler, D. 1., \& Biner, P. m. (1989). Effects of settings on window preferences and factors associated with those preferences. Environment and Behavior, 21(1): 17-31.

Butler, D. L., \& Steuerwald, B. L. (1991). Effects of view and room size on window size preferences made in models. Environment and Behavior, 23(3): 334-358. https://doi.org/10.1177/0013916591233005

Chong, E. E., Nazim, A., \& Ahmad, S. B. (2014). A comparison between Individual confirmatory factor analysis and pooled confirmatory factor 
analysis: An analysis of library service quality, a case study at a public university in Terengganu. Interational Journal of Engineering Science and Innovative Technology, 3(1): 110-116.

Collins, B. L. (1976). Review of the psychological reaction to windows. Lighting Research \& Technology. 8(2): 80-88 https://doi.org/10.1177/14771535760080020601

Cuce, E., Young, C. H., \& Riffat, S. B. (2015). Thermal performance investigation of heat insulation solar glass: A comparative experimental study. Energy and Buildings, 86: 595-600. https://doi.org/10.1016/j.enbuild.2014.10.063

Danielsson, B. C., \& Bodin, L. (2008). Office type in relation to health, well-being, and job satisfaction among employees. Environment and Behavior, 40(5): 636-668. https: / / doi.org/10.1177/0013916507307459

Dogrusoy, I. T., \& Tureyen, M. (2007). A field study on determination of preferences for windows in office environments. Building and Environment, 42(10): 3660-3668. https://doi.org/10.1016/j.buildenv.2006.09.010

Frontczak, M., \& Wargocki, P. (2011). Literature survey on how different factors influence human comfort in indoor environments. Building and Environment, 46(4): 922-937. https://doi.org/10.1016/j.buildenv.2010.10.021

Hair, J. F., Black, W. C., Barry J. Babin, \& Anderson, R. E. (2017). Multivariate Data Analysis (MVDA). Pharmaceutical Quality by Design: A Practical Approach. https://doi.org/10.1002/9781118895238.ch8

Hartig, T., Mang, M. \&, \& Evans, G. W. (1991). Restorative Effects of Natural Environment Experiences. Environment and Behavior, 23(1): 3 26.

Hartig, Terry, Evans, G. W., Jamner, L. D., Davis, D. S., \& Gärling, T. (2003). Tracking restoration in natural and urban field settings. Journal of Environmental Psychology, 23(2): 109-123. https://doi.org/10.1016/S0272-4944(02)00109-3

Heerwagen, J. H., \& Orians, G. H. (1986). Adaptations to windowlessness, a study of the use of visual decor.pdf. Environment and Behavior, 18(5): 623-639.

Hellinga, H. (2013). Daylight and View, The influence of windows on the visual quality of indoor spaces, 53. https://doi.org/10.1017/CBO9781107415324.004

Henseler, J., Ringle, C. M., \& Sinkovics, R. R. (2009). The use of partial least squares path modeling in international marketing. Advances in International Marketing, 20: 277-319. https://doi.org/10.1108/S14747979(2009)0000020014

Herzog, T. R., Kaplan, S., \& Kaplan, R. (1976). The prediction of preference for familiar.pdf. SAGE Social Sciencs Collections, 8(4): 627-645.

Hox, J. J., \& Bechger, T. M. (1999). An introduction to structural equation modeling. Studies in Health Technology and Informatics, 213(November): 3-6. https://doi.org/10.3233/978-1-61499-538-8-3

Inan, T. (2013). An investigation on daylighting performance in educational institutions. Structural Survey, 31(2): 121-138. https: / / doi.org/10.1108/02630801311317536

Jamrozik, A., Clements, N., Hasan, S. S., Zhao, J., Zhang, R., Campanella, C. Bauer, B. (2019). Access to daylight and view in an office improves cognitive performance and satisfaction and reduces eyestrain: A controlled crossover study. Building and Environment, 165(March): 106379. https:// doi.org/10.1016/j.buildenv.2019.106379

Jiang, S. (2016). Encouraging engagement with therapeutic landscapes: Using tranparent spaces to optimize stress reduction in urban health facilities. Dissertation Abstracts International Section A: Humanities and Social Sciences, 76(10-A(E)): 1-218. Retrieved January 24, 2020, from http:/ / gateway.proquest.com/openurl?url_ver=Z39.88-

2004\&rft_val_fmt $=$ info:ofi/fmt:kev:mtx:dissertation\&res_dat $=$ xri:pqm \&rft_dat=xri:pqdiss:3705145\%5Cnhttp://ovidsp.ovid.com/ovidweb.cg $\mathrm{i} ? \mathrm{~T}=\mathrm{JS} \& \mathrm{PAGE}=$ reference $\& \mathrm{D}=\mathrm{psyc} 12 \& \mathrm{NEWS}=\mathrm{N} \& A \mathrm{~N}=2016-16229$ 063

Kamarulzaman, N., Saleh, A. A., Hashim, S. Z., \& Hashim, H. (2011). Procedia Engineering An Overview of the Influence of Physical Office Environments towards Employees. Procedia Engineering, 20: 262-268. https://doi.org/10.1016/j.proeng.2011.11.164

Kaplan, R. (1993). The role of nature in the context of the workplace. Landscape and Urban Planning, 26(1-4): 193-201. https://doi.org/10.1016/0169-2046(93)90016-7

Kaplan, R., \& Kaplan, S. (1989). The Experience of Nature: A Psychological Perspective (illustrate). CUP Archive.

Kaplan, S. (1987). Aesthetics, Affect, and Cognition Environmental Preference from an Evolutionary Perspective.

Konstantzos, I, \& Tzempelikos, A. (2015). Design Recommendations for Perimeter Office, 271-276.

Konstantzos, Iason, Chan, Y. C., Seibold, J. C., Tzempelikos, A., Proctor, R. W., \& Protzman, J. B. (2015). View clarity index: A new metric to evaluate clarity of view through window shades. Building and Environment, 90: 206-214. https://doi.org/10.1016/j.buildenv.2015.04.005

Koohsari, A. M., Fayaz, R., \& Kari, B. M. (2015). The Influence of Window Dimensions and Location on Residential Building Energy Consumption by Integrating Thermal and Lighting Analysis in a Mild and Humid Climate. MAGNT Research Report, 3(4): 187-194. https://doi.org/dx.doi.org/14.9831/1444-8939.2015/34/MAGNT.19

Koranteng, C, Essel, C., \& Nkrumah, J. (2015). Passive Analysis of the Effect of Window Size and Position on Indoor Comfort for Residential Rooms in Kumasi, Ghana. Iarjet, 2(10): 114-115. https://doi.org/10.17148/IARJSET.2015.21024

Koranteng, Christian, Nkrumah, J., \& Essel, C. (2016). An Experimental Assessment of the Efficiency of Glazing Types Used As Cladding Materials for Multi-Storey Office Buildings in Ghana, 2(1): 1-9.

Kwon, M., \& Remøy, H. (2019). Office employee satisfaction: the influence of design factors on psychological user satisfaction. Facilities, 38(1-2): 1-19. https://doi.org/10.1108/F-03-2019-0041

Kwon, M., Remøy, H., \& van den Bogaard, M. (2019). Influential design factors on occupant satisfaction with indoor environment in workplaces. Building and Environment, 157(May): 356-365. https://doi.org/10.1016/j.buildenv.2019.05.002

Leather, P., Pyrgas, M., Beale, D., \& Lawrence, C. (1998). Windows in the Work Place,Sunlight, View, and Occupational Stress. Environment and Behavior, 30(6): 739-762. 
Leder, S., Newsham, G. R., Veitch, J. A., Mancini, S., \& Charles, K. E. (2016). Effects of office environment on employee satisfaction: A new analysis. Building Research and Information, 44(1): 34-50. https://doi.org/10.1080/09613218.2014.1003176

Leslie, R. P. (2003). Capturing the daylight dividend in buildings: Why and how? Building and Environment, 38(2): 381-385. https://doi.org/10.1016/S0360-1323(02)00118-X

Lindberg, C. M., Srinivasan, K., Gilligan, B., Razjouyan, J., Lee, H., Najafi, B., ... Sternberg, E. M. (2018). Effects of office workstation type on physical activity and stress. Occupational and Environmental Medicine, 75(10): 689-695. https://doi.org/10.1136/oemed-2018-105077

Lottrup, L., Stigsdotter, U. K., Meilby, H., Claudi, A. G., Lottrup, L., Stigsdotter, U. K., ... Claudi, A. G. (2015). The Workplace Window View: A Determinant of Office Workers' Work Ability and Job Satisfaction The Workplace Window View : A Determinant of Of fi ce Workers' Work Ability and Job Satisfaction. Landscape Research, 40(1): 57-75. https://doi.org/10.1080/01426397.2013.829806

Madu, N. G., Asawo, P. S., \& Gabriel, O. M. J. (2017). Physical Workplace Environment and Employees' Engagement: A Theoritical Exploration. International Journal of Arts and Humanities, 01(10): 867-884.

Matusiak, B. S., \& Klöckner, C. A. (2016). How we evaluate the view out through the window. Architectural Science Review, 59(3): 203-211. https://doi.org/10.1080/00038628.2015.1032879

Moore, E. O. (1981). Prison Environment'S Effect on Health Care Service Demands. Journal of Environmental Systems, 11(1): 17-34. https://doi.org/10.2190/KM50-WH2K-K2D1-DM69

Morrison, R. L., \& Macky, K. A. (2017). The demands and resources arising from shared office spaces. Applied Ergonomics, 60: 103-115. https://doi.org/10.1016/j.apergo.2016.11.007

Ne'eman, E., Sweitzer, G., \& Vine, E. (1984). Office worker response to lighting and daylighting issues in workspace environments: A pilot survey. Energy and Buildings, 6(2): 159-171. https://doi.org/10.1016/03787788(84)90071-9

Oseland, N. (2009). The impact of psychological needs on office design. Journal of Corporate Real Estate. 11(4): 244-254. https://doi.org/10.1108/14630010911006738

Ozdemir, A. (2010). The effect of window views' openness and naturalness on the perception of rooms' spaciousness and brightness: A visual preference study. Scientific Research and Essays. 5(16): 2275-2287. Retrieved from http://www.academicjournals.org/journal/SRE/articleabstract/C49A20017716

Pallant, J. (2016). For the SPSS Survival Manual Astep by step guide to data analysis using IBM SPSS. Open University Press.

Qureshi, S. M., \& Kang, C. W. (2015). Analysing the organizational factors of project complexity using structural equation modelling. International Journal of Project Management, 33(1): 165-176. https://doi.org/10.1016/j.ijproman.2014.04.006
Salonen, H., Lahtinen, M., Lappalainen, S., Knibbs, L. D., Morawaska, L., \& Reijula, K. (2014). The impact of windows, daylight and views of nature on health and wellbeing in healthcare facilities. The International Sustainable Built Environment Conference, (January), 28-30.

Samani, S. A. (2015). The Impact of Personal Control over Office Workspace on Environmental Satisfaction and Performance. Journal of Social Sciences and Humanities, 1(3): 163-172. Retrieved from http://www.aiscience.org/journal/jssh Retrieved May 28, 2020

Sant'Anna, . O., Dos Santos, P. H., Vianna, N. S., \& Romero, M. A. (2018). Indor environmental quality perception and users' satisfaction of conventional and green buildings in Brazil. Sustainable Cities and Society, 43(August): 95-110. https://doi.org/10.1016/j.scs.2018.08.027

Thompson, A., \& Bruk-Lee, V. (2019). Naturally! Examining Nature's Role in Workplace Strain Reduction. Occupational Health Science, 3(1): 23 43. https://doi.org/10.1007/s41542-019-00033-5

Ulrich, R. S. (1984). View through a window may influence recovery from $\begin{array}{lll}\text { surgery. } & \text { Science, } & \text { 224(4647): }\end{array}$ https://doi.org/10.1126/science.6143402

Ulrich, Roger S., Simons, R. F., Losito, B. D., Fiorito, E., Miles, M. A., \& Zelson, M. (1991). Stress recovery during exposure to natural and urban environments. Journal of Environmental Psychology, 11(3): 201-230. https:// doi.org/10.1016/S0272-4944(05)80184-7

Ulrich, Roger S. (1993). Biophilia, Biophobia, and Natural Landscapes. The Biophilia Hypothesis, (November), 73-137. https://doi.org/citeulikearticle-id:7372161

Van Der Valk, S., Myers, T., Atkinson, I., \& Mohring, K. (2015). Sensor networks in workplaces: Correlating comfort and productivity. 2015 IEEE 10th International Conference on Intelligent Sensors, Sensor Networks and Information Processing, ISSNIP 2015, (April), 1-6. https://doi.org/10.1109/ISSNIP.2015.7106905

Verderber, S., Grice, S., \& Gutentag, P. (1987). Wellness health care and the architectural environment. Journal of Community Health, 12(2-3): 163175. https://doi.org/10.1007/BF01323478

Wong, K. K. K.-K. (2013). 28/05 - Partial Least Squares Structural Equation Modeling (PLS-SEM) Techniques Using SmartPLS. Marketing Bulletin, 24(1): 1-32. Retrieved from http://marketingbulletin.massey.ac.nz/v24/mb_v24_t1_wong.pdf\%5Cnhttp://www.re searchgate.net/profile/Ken_Wong10/publication/268449353_Partial_ Least_Squares_Structural_Equation_Modeling_(PLSSEM)_Techniques_Using_SmartPLS/links/54773b1b0cf293e2da25e3f3. pdf

Yildirim, K., Akalin-baskaya, A., \& Celebi, M. (2007). The effects of window proximity, partition height, and gender on perceptions of openplan offices. Journal of Environmental Psychology, 27(2): 154-165. https://doi.org/10.1016/j.jenvp.2007.01.004

Zubairu, S. N., \& Olagunju, R. E. (2003). A Study of Space Planning in Private and Government Office Buildings in Abuja and Minna, (April). 